\title{
Party Positions on the European Constitution During the 2004 European Parliament Elections
}

\author{
Christine Arnold \& Paul Pennings
}

\begin{abstract}
The salience assigned to the European Constitution and the positions on it taken by national parties during the 2004 European Parliament elections are the focus of this paper. To explore these issues, we use party manifestos, expert data on party positions, and public opinion survey data from Eurobarometer. Through content analysis of the manifestos we find that the Constitution has been politicised and contested. In countries where the issue has been put in the spotlight by one or more parties, other parties also have had to take a position. The positions parties have taken on the Constitution are related to their overall position on European integration, whether or not they participated in the Constitutional Convention, and their left/right stance.
\end{abstract}

THE PROCESS OF DEEPENING AND WIDENING THE EUROPEAN UNION (EU) CAN BE expected to alter contestation among political parties in the member states. Political competition between parties during elections might no longer be fully insulated from the issues battled out at the EU level. Instead, parties could seek to better position themselves relative to their competitors by invoking broader European issues. Such an impact might especially be expected after episodes of intensive deliberations or Treaty negotiations at the EU level, such as the recent efforts to draft a constitutional treaty. The 'Convention on the Future of Europe' (Constitutional Convention) not only discussed sensitive issues, but also, due to its innovative working method, gave national and European party actors an unprecedented opportunity to participate actively in EU-level deliberations.

Studying national party positions regarding the EU Constitution is important for helping us to understand party attitudes toward the EU more generally. A further recent concern in the literature is how European integration affects party competition. This paper contributes to these debates by considering the positions on the Constitution taken by parties during the 2004 European Parliament (EP) elections. Our central research question is how, if at all, the constitutional discussions affected political contestation in those elections. More specifically, did parties politicise the constitutional issue during the election campaign and take clearly discernible positions along partisan lines? In order to answer this question, our research focuses on the salience parties assigned to and positions they took on the Constitution.

Our research consists of content analysis of references to the Constitution in manifestos issued for the June 2004 EP elections. Additionally, this paper uses the expert opinions in the 2002 Chapel Hill dataset (Hooghe 2009) and the expert data from Benoit and Laver (2006) to capture parties' overall positions on European

ISSN 1815-347X online. Arnold, C. and Pennings, P. (2009). 'Party Positions on the European Constitution During the 2004 European Parliament Elections', Journal of Contemporary European Research, Vol. 5, No. 1, pp. 24-42.

Available: http://www.jcer.net/ojs.index.php/jcer/article/view/66/135 
integration, their degree of internal division on the issue, and where they stand on a left/right scale. Further, to assess the potential influence of public opinion on the salience parties assign to the Constitution, we use survey data from Eurobarometer 61.0, conducted in spring 2004.

The paper is structured as follows: in the following section we discuss briefly the nature of party competition in multi-level settings and relate this to party positions on the Constitution, in order to arrive at testable propositions. In the third section we describe the data used for the empirical exploration of our hypotheses. In the fourth section we present the empirical findings and draw out the implications of our results for the hypotheses. Finally, we conclude the article with a discussion about the relevance of our findings.

\section{Understanding Party Competition through Salience Theory and Cleavage Theory}

The literature on the impact of European integration on national party systems arrives at contradictory conclusions. On the one hand, there are scholars who view national party systems as impervious to the influence of European issues; they argue that there is no dimension of party competition focused on Europe. Instead, national political elites collude to depoliticise European issues (Mair 2001 and 2007). Further, EP elections are seen merely as second-order elections (Franklin et al. 1994; Irwin 1995; Reif and Schmitt 1980). National political parties do not compete for votes using a European based platform, but rather by a selection of national issues guided by short-term considerations, such as challenging the performance of the incumbent government.

On the other hand, there are scholars who argue that Europe is becoming a more salient issue in political discussions. These scholars have found a remarkable degree of coherence in the way parties with a similar ideological position accommodate European issues in their election campaigns (Gabel and Hix 2002; Marks et al. 2002; Pennings 2002). Their work suggests that support for European integration partly overlaps with the partisan structuring of the left/right axis and in fact can be seen as an inverted U-curve (Hooghe et al. 2004: 129). Additionally, the argument has been made that those aspects of European integration that cannot easily be incorporated into the left/right axis emerge as a distinct pro-/anti-integration dimension (Marks and Steenbergen 2004). In this dimension, parties take clearly discernible and predictable positions. Furthermore, analysis of roll-call votes indicates that, due to high levels of political group cohesion, Members of the European Parliament (MEPs) are more prone to vote according to ideology than to nationality (Attina 1990; Hix 1999 and 2001; Hix et al. 2003; Kreppel and Tsebelis 1999).

It has been shown that differences in the degree to which parties of left and right support European integration are largest at the disaggregated level of issues. EU policies related to political regulation of the market, such as cohesion policy, and policies with distributional effects, such as social, employment, environmental and trade policies, are most closely connected to the left/right dimension (Marks and Steenbergen 2004).

Hooghe and Marks have argued that since the early 1990s there has been a constraining dissensus on European issues, replacing the permissive consensus of the previous phase of European integration (Hooghe and Marks 2009). Elite decisions about European issues can now engage mass publics, in particular when national identity or authority is at stake. European constitution-making is relevant to partisan politics, including in the context of the 2004 EP elections. The Constitution is contested at the national level since not all parties support increasing European integration and some want to halt it. Whether or not an issue becomes politicised depends on whether one or more parties take it up. As European integration has grown in scope and depth, it has proven ripe for politicisation (Hooghe and Marks 2009). If the Constitution is 
conceived of as a major symbol and result of increasing European integration, studying how it is handled by national parties during the 2004 EP elections can enable us to determine to what extent European integration has affected national party competition.

Our main objective in this paper is to analyse the degree to which the recent constitution-building process at the EU level influenced political competition during the 2004 EP elections. By this we aim to contribute to the literature examining the impact of European integration on national party systems. To this end, we specify a number of propositions regarding salience (derived from salience theory) and positiontaking (derived from cleavage theory) since both are indicators of the degree to which political parties polarised on the Constitution.

EP election campaigns focus mainly on national issues, and voters in EP elections are motivated by national-level criteria and not by European issues (Van der Eijk and Franklin 1996). This second-order nature of EP elections affects the way in which parties discuss the Constitution in manifestos, that is, in dealing with it they will take into account the national political context, and, in particular, party competition. For this reason, we focus on the degree to which the salience that each party assigns to the constitutional issue is affected by the salience that other parties in the party system assigned to it.

Salience theory predicts that during election campaigns parties emphasise the types of issues that favour themselves, in order to accomplish certain goals, such as electoral success or maintaining party cohesion (Budge and Farlie 1983; Budge et al. 2001; Klingemann et al. 1994; Riker 1982; Schmitt and Thomassen 1999). Conversely, parties devote considerably less attention to those issues that they believe might work in favour of competing parties or party groups. Parties seek to avoid a direct confrontation of opposing policies. Instead, they will selectively emphasise the strong points of their own case (Budge and Farlie 1983: 24). In doing so, certain types of parties have become widely perceived as 'owning' certain issue types, for example, the welfare state, law and order, the environment, religion. Electors are expected to vote for the party that puts most emphasis on the issues important to them. Recent research has shown that parties have been inclined to de-emphasise the European integration issue in their manifestos (Pennings 2006; Poguntke et al. 2007). However, parties that oppose the Constitution might have a strong incentive to put this issue on the agenda if they hope to benefit electorally from a disequilibrium in the political system caused by them introducing this issue.

It should be noted, however, that the tactical choice a party makes whether to emphasise or de-emphasise the Constitution is not made in a vacuum. We expect to find that it would be related to the choices made by competing parties. As Steenbergen and Scott point out, "the salience of an issue is determined by many factors, not least of which is the behaviour of other parties. A party can ignore those factors only at the risk of removing itself from the mainstream political debate" (2004: 169). Thus, the more that one party emphasises the Constitution as an issue, the more it creates pressure on other parties in the same political system to do the same. This might imply that the salience of a particular topic for a given party is determined more by the salience of that topic for competing parties than by its own preferences. In that sense, the tactical choice of each party is related to the sum of the choices made by parties in the same political system. Therefore, we will examine to what extent the salience assigned to the Constitution by the parties collectively in a given country is related to the salience assigned to it by parties individually.

Cleavage theory identifies the ideological location of a party as a powerful predictor of the position it will take on European integration in general and the EU Constitution in particular. Ideological positions constrain the way parties respond to new issues and new challenges. It is commonly assumed that the left/right divide is the main factor 
structuring the positions parties take during competition (Marks and Wilson 2000; Hooghe et al. 2004). Both the concern to preserve the loyalty of established constituencies, and the legacy of past agendas limit the range of possible responses parties have to new issues.

Issues concerning European integration have been shown to be cross-cutting, capable of causing dissent within parties and party families (Thomassen et al. 2004). An imbalance in the degree to which economic and political integration are favoured can fuel intra-party dissent. Some parties are more vulnerable to internal dissent than others. Examples are conservative parties that favour economic integration rather than political integration, and socialist parties in countries with a traditionally strong social democracy that favour political integration rather than economic integration (Steenbergen and Scott 2004).

Marks and Hooghe have demonstrated that the relationship between left/right and European integration is shaped as an inverted U-curve. This shape of the distribution is due to three factors: first, extreme left and extreme right parties at either end of the ideological spectrum show very low levels of support for European integration; second, centre-left parties have become increasingly inclined to support a European regulatory system, while centre-right parties continue to fear the erosion of national decisionmaking prerogatives; third, centrist parties (i.e. social democratic, Christian democratic, liberal, and conservative parties) generally show high levels of support for European integration (Hooghe et al. 2004: 129). Clearly discernible left/right stances coincide strongly with pro- and anti-EU positions, especially in the case of socio-economic policy areas. For example, left parties will favour more EU involvement in the areas of employment, social policies, etc., and right parties will oppose such a course (Marks and Steenbergen 2004).

The Constitutional Convention took place from February 28, 2002 to July 10, 2003 and addressed substantial EU institutional and constitutional matters that were considered to have been left over from previous rounds of Treaty reform. In December 2001, the European Council in Laeken laid out not only the procedural details of when it should convene and how it should be constituted, but also the goals and the objectives of such a Convention. According to the Laeken Declaration, the Convention should tackle a wide range of issues: the division of competences between the Union and its member states; how to simplify the Union's legislative instruments; how to maintain interinstitutional balance; how to make decision-making more effective; the definition of the EU's role in an increasingly global environment; and the constitutionalisation of the Treaties. These issues clearly pointed to a change to the status quo and thus required national parties to take a position which might differ from their accustomed attitude toward European integration.

During the Convention, out of all the delegates and observers from the member states and the acceding countries, only 66 had the right to vote, that is, one governmental and two parliamentary representatives from each member state (König and Hug 2006). In most cases, these representatives were members of established parties that often participated in government. The absence of many extremist and new parties during the Convention helped the process of consensus building. A large majority of the delegates was pro-Europe and in favour of the Constitution. During the referenda held on the Constitution, particularly in France and the Netherlands, some of the parties that had not participated in the Convention actively and successfully mobilised voters to vote against it (Crum 2007; Pennings and Arnold 2008).

\section{Data, Method and Measurement}

In order to measure the salience of the Constitution for parties, and the position they took on it during the 2004 EP elections, we collected national party manifestos issued 
for this election. We selected parties that won at least one seat in the current Parliament. This selection criterion gave a total of 100 manifestos. Table 1 lists the parties included.

Table 1: List of Parties

\begin{tabular}{|c|c|c|c|}
\hline Country & Party Label & Party Name & Party Name Translated \\
\hline \multicolumn{4}{|c|}{ Sweden (SE) } \\
\hline & junilistan & Junilistan & The June List \\
\hline & MP & Miljöpartiet de Gröna & The Environmental Party \\
\hline & V & Vänsterpartiet & Left Party \\
\hline & $S$ & $\begin{array}{l}\text { Arbetarepartiet- } \\
\text { Socialdemokraterna }\end{array}$ & $\begin{array}{l}\text { Workers' Party-Social } \\
\text { Democrats }\end{array}$ \\
\hline & FP & Folkpartiet Liberalerna & People's Party Liberals \\
\hline & KD & Kristdemokraterna & Christian Democrats \\
\hline & M & Moderata Samlingspartiet & Moderate Rally Party \\
\hline & C & Centerpartiet & Centre Party \\
\hline \multicolumn{4}{|c|}{ Denmark (DK) } \\
\hline & FolkB & Folkebevægelsen & Popular Movement \\
\hline & JuniB & JuniBevægelsen & June Movement \\
\hline & SF & Socialistisk Folkeparti & Socialist People's Party \\
\hline & SD & $\begin{array}{l}\text { Socialdemokratiet i } \\
\text { Danmark }\end{array}$ & Social Democracy Party in Denmark \\
\hline & RV & Radikale Venstre & $\begin{array}{l}\text { Radical Left-Social } \\
\text { Liberal Party }\end{array}$ \\
\hline & $\mathrm{V}$ & $\begin{array}{l}\text { Venstre, Danmarks } \\
\text { liberale parti }\end{array}$ & $\begin{array}{l}\text { Left, Liberal Party } \\
\text { of Denmark }\end{array}$ \\
\hline & KF & Konservative Folkeparti & Conservative People's Party \\
\hline & DF & Dansk Folkeparti & Danish People's Party \\
\hline \multicolumn{4}{|c|}{ Finland (FI) } \\
\hline & VAS & Vasemmistoliitto & Left Wing League \\
\hline & SDP & $\begin{array}{l}\text { Suomen Sosialidemokraattinen } \\
\text { Puolue }\end{array}$ & $\begin{array}{l}\text { Social Democratic } \\
\text { Party of } \\
\text { Finland }\end{array}$ \\
\hline & KOK & Kansallinen Kokoomus & National Rally \\
\hline & KESK & Suomen Keskusta & Finnish Centre \\
\hline & SFP & $\begin{array}{l}\text { Svenska Folkpartiet } \\
\text { i Finland }\end{array}$ & $\begin{array}{l}\text { Swedish People's } \\
\text { Party }\end{array}$ \\
\hline \multicolumn{4}{|c|}{ Netherlands (NL) } \\
\hline & CU/SGP & $\begin{array}{l}\text { Christen Unie - } \\
\text { Staatkundig } \\
\text { Gereformeerde Partij }\end{array}$ & $\begin{array}{l}\text { Christian Union - } \\
\text { Political Reformed } \\
\text { Party }\end{array}$ \\
\hline & EurTrans & Europa Transparant & Europe Transparent \\
\hline & Groen Links & Groen Links & Green Left \\
\hline & SP & Socialistische Partij & Socialist Party \\
\hline & PvdA & Partij van de Arbeid & Labour Party \\
\hline & D66 & Democraten 66 & Democrats 66 \\
\hline & VVD & $\begin{array}{l}\text { Volkspartij voor Vrijheid } \\
\text { en Democratie }\end{array}$ & $\begin{array}{l}\text { People's Party for Freedom } \\
\text { and Democracy }\end{array}$ \\
\hline & CDA & Christen Democratisch Appel & Christian Democratic Appeal \\
\hline
\end{tabular}




\begin{tabular}{|c|c|c|c|}
\hline Country & Party Label & Party Name & Party Name Translated \\
\hline \multicolumn{4}{|c|}{ Belgium (BE) } \\
\hline & $\mathrm{N}-\mathrm{VA}$ & Nieuw-Vlaamse Alliantie & New Flemish Alliance \\
\hline & MR & Mouvement Réformateur & Reformist Movement \\
\hline & $\mathrm{CDH}$ & Centre Démocrate Humaniste & $\begin{array}{l}\text { Christian Social } \\
\text { Party }\end{array}$ \\
\hline & CSP & Christlich Soziale Partei & Christian Social Party \\
\hline & ECOLO & Ecolo & Ecologists \\
\hline & GROEN & Agalev & Ecologists \\
\hline & SPA-SPIRIT & Sociaal Progressief Alternatief & $\begin{array}{l}\text { Socialist Party } \\
\text { (Flemish) }\end{array}$ \\
\hline & PS & Parti Socialiste & Socialist Party (Walloon) \\
\hline & VLD-VIVANT & $\begin{array}{l}\text { Vlaamse Liberalen en } \\
\text { Democraten }\end{array}$ & Flemish Liberals and Democrats \\
\hline & CD\&V-N-VA & Christen-Democratisch \& Vlaams & $\begin{array}{l}\text { Christian People's } \\
\text { Party }\end{array}$ \\
\hline & VLAAMS BLOK & Vlaams Blok & Flemish Block \\
\hline & UMP & $\begin{array}{l}\text { Rassemblement pour la } \\
\text { République }\end{array}$ & $\begin{array}{l}\text { Rally for the } \\
\text { Republic }\end{array}$ \\
\hline & FN & Front National & National Front \\
\hline \multicolumn{4}{|l|}{ Italy (IT) } \\
\hline & Fed Verdi & Federazione dei Verdi & Federation of Greens \\
\hline & PIETRO & Lista di Pietro - Italia dei Valori & List di Pietro Parties - Italy of Values \\
\hline & LBONINO & Lista Pannella Bonino & List Pannella Bonino \\
\hline & Pensionati & Partito Pensionati & Pensioners' Party \\
\hline & NPSI & Nuovo Partito Socialista Italiano & $\begin{array}{l}\text { New Italian } \\
\text { Socialist Party }\end{array}$ \\
\hline & $\mathrm{PdCl}$ & Partito dei Comunisti Italiani & $\begin{array}{l}\text { Party of the Italian } \\
\text { Communists }\end{array}$ \\
\hline & UDC & $\begin{array}{l}\text { I'Unione dei Democratici } \\
\text { Cristiani e Democratici } \\
\text { e di Centro }\end{array}$ & $\begin{array}{l}\text { Union of Christian } \\
\text { and Centre Democrats }\end{array}$ \\
\hline & UDEUR-AP & Unione Democratici per l'Europa & $\begin{array}{l}\text { Union of Democrats } \\
\text { for Europe }\end{array}$ \\
\hline & $\mathrm{RC}$ & Rifondazione Comunista & Communist Refoundation \\
\hline & DS/ULIVIO & Democratici di Sinistra & Democrats of the Left \\
\hline & $\mathrm{FI}$ & Forza Italia & Forwards Italy \\
\hline & AN & Alleanza Nazionale & National Alliance \\
\hline & LN & Lega Nord & Northern League \\
\hline \multicolumn{4}{|l|}{ Spain (ES) } \\
\hline & PP & Partido Popular & People's Party \\
\hline \multicolumn{4}{|c|}{ Greece (GR) } \\
\hline & PASOK & Panellino Socialistiko Kinima & Pan-Hellenic Socialist Movement \\
\hline & ND & Nea Dimokratia & New Democracy \\
\hline \multicolumn{4}{|c|}{ Portugal (PT) } \\
\hline & PCP & Partido Comunista Português & Portuguese Communist Party \\
\hline & CDU & Coligação Democrática Unitária & Unitarian Democratic Coalition \\
\hline & PS & Partido Socialista & Socialist Party \\
\hline & PSD & Partido Social Democrata & Social Democratic Party \\
\hline
\end{tabular}




\begin{tabular}{|c|c|c|c|}
\hline Country & Party Label & Party Name & Party Name Translated \\
\hline \multicolumn{4}{|c|}{ Germany (DE) } \\
\hline & $\begin{array}{l}\text { Buendis/ } \\
\text { Gruene }\end{array}$ & Bündnis 90/Die Grünen & Alliance $90 /$ The Greens \\
\hline & PDS & $\begin{array}{l}\text { Partei des Demokratischen } \\
\text { Sozialismus }\end{array}$ & $\begin{array}{l}\text { Party of Democratic } \\
\text { Socialism }\end{array}$ \\
\hline & SPD & $\begin{array}{l}\text { Socialdemokratische Partei } \\
\text { Deutschlands }\end{array}$ & $\begin{array}{l}\text { Social Democratic Party } \\
\text { of Germany }\end{array}$ \\
\hline & FDP & Freie Demokratische Partei & Free Democratic Party \\
\hline & CDU & Christlich-Demokratische Union & Christian-Democratic Union \\
\hline \multicolumn{4}{|c|}{ Austria (AT) } \\
\hline & Gruene & Die Grünen & The Greens \\
\hline & SPO & $\begin{array}{l}\text { Sozialdemokratische Partei } \\
\text { Österreichs }\end{array}$ & $\begin{array}{l}\text { Social Democratic Party } \\
\text { of Austria }\end{array}$ \\
\hline & FPO & Freiheitliche Partei Österreichs & Freedom Party of Austria \\
\hline & OVP & Österreichische Volkspartei & Austrian People's Party \\
\hline \multicolumn{4}{|c|}{$\begin{array}{l}\text { United Kingdom } \\
\text { (GB) }\end{array}$} \\
\hline & Greens & Green Party & Green Party \\
\hline & CYMRU & Plaid Cymru & The Party of Wales \\
\hline & UKIP & UK Independence Party & UK Independence Party \\
\hline & UUP & Ulster Unionist Party & Ulster Unionist Party \\
\hline & $L A B$ & Labour Party & Labour Party \\
\hline & LD & Liberal Democrats & Liberal Democrats \\
\hline & Cons & Conservative Party & Conservative Party \\
\hline & SNP & Scottish National Party & Scottish National Party \\
\hline \multicolumn{4}{|l|}{ Ireland (IE) } \\
\hline & FG & Fine Gael & Family of the Irish \\
\hline & FF & Fianna Fáil & Soldiers of Destiny \\
\hline & SF & Sinn Féin & We Ourselves \\
\hline
\end{tabular}

After translation, the manifestos were manually coded using a detailed coding scheme. ${ }^{1}$ Each sentence was assigned to a pre-defined category, based on the expert questionnaire developed for the measurement of positions on the Constitution in the EU-funded DOSEI project. ${ }^{2}$ Finally, all codes were aggregated and normalised against

${ }^{1}$ The manifestos were machine-translated using software for each language that produces the best results (for example the Systran Software in the cases of Spanish, Italian, German, French and Portuguese). Although the translations were often grammatically not quite correct, the meaning of the text was clear and manual coding was possible. The use of manual and computer-aided content analysis in the social sciences has a long tradition and has been applied to a range of subfields and research questions (Bara 2001; Laver and Garry 2000; Laver 2001; Kleinnijenhuis and Pennings 2001; Pennings and Keman 2002; Gabel and Hix 2002; Hix 1999).

2 The DOSEl group studied the constitution building process from the Laeken convention until the ratification in all Member States. Thomas König coordinated the work of 20 political scientists from eight European and US universities. The project received funding from the Commission's 5th Framework Programme. For more details on the DOSEI project see König and Hug (2006) and Tsebelis (2005). Among the different methodological approaches in content analysis, the following two are most often referred to: the wordscoring technique (Laver et al. 2003; Benoit et al. 2005) and the dictionary based technique (Pennings and Keman 2002; Pennings and Arnold 2008; and Pennings et al. 2004). 
the length of the document, allowing us to take into account the variable length of all the documents.

We have two dependent variables in our analysis: salience of the Constitution; and party position on the Constitution. We operationalise salience of the Constitution as the total number of sentences, both positive and negative, about the Constitution as a proportion of the total sentences in a manifesto. We operationalise party position on the Constitution as the proportion of positive to negative sentences about the Constitution.

We provide an hypothesis which states that the salience of the Constitution to an individual party is related to the collective salience among all the other parties, the socalled systemic salience. Systemic salience is measured as the mean of the salience score of all parties in a given system, after excluding the party under consideration (Steenbergen and Scott 2004: 173). For example, given a country with three parties, $A$, $B$, and $C$, the systemic salience with respect to party $A$ is defined as the mean salience level of parties $B$ and $C$. This measure is reported in preference to average national salience, in order to avoid endogeneity problems. Additionally, we examine whether variation in salience across countries and party systems is related to differences in public support for or polarisation in attitudes toward European integration. For this analysis we use Eurobarometer survey 61.0 which was conducted in spring 2004. In particular, we make use of the question that asked respondents whether they were for or against the Constitution.

We use the expert opinions in the Chapel Hill dataset (Hooghe et al. 2002) to test whether party position on the Constitution is related to internal divisions on European integration, the overall position of a party on European integration, or the left/right stance of a party. We supplement the Chapel Hill dataset with the expert data from Benoit and Laver (2006), since not all relevant countries and parties are covered in the Chapel Hill dataset. ${ }^{3}$ The Chapel Hill 2002 expert survey on party positioning on European integration covers 171 parties in 23 of the 25 current EU member states (not Luxembourg and Estonia) as well as in Bulgaria and Romania. From these countries we select those member states that belonged to the EU prior to 1 May 2004. The survey was administered between September 2002 and April 2003 to 636 academics specialising in parties or European integration. The survey includes a question about internal dissent or conflict in the party concerning European integration. ${ }^{4}$ Additionally, the survey includes a question about a party's general position on European integration. ${ }^{5}$ The survey also includes a question about a party's ideological stance in 2002 on economic issues (role of government in the economy). ${ }^{6}$

\footnotetext{
${ }^{3}$ K. Benoit, M. Laver (2009) Party Policy In Modern Democracies. Expert Survey Results from 47 Countries, 2003-2004, available at: http://www.tcd.ie/Political Science/ppmd/, last accessed 9 April 2009. From this expert survey we use question 13 which has the following wording: "Please locate each party on a general left-right dimension, taking all aspects of party policy into account." The possible answers range from 1 (Left) to 20 (Right).

${ }^{4}$ This is question 12 in the Chapel Hill expert survey. The wording of this question is: "How much internal dissent has there been in the various parties in [COUNTRY] over European integration over the course of 2002?" The possible answers range from 1 "party is completely united" to 10 "party is extremely divided."

${ }^{5}$ This is question 1 in the Chapel Hill expert survey. The wording of this question is: "How would you describe the general position on European integration that the party's leadership has taken over the course of 2002?" Possible answers to this question range from 1 "strongly opposed to European integration" to 7 "strongly in favour of European integration."

${ }^{6}$ This is question 15 in the Chapel Hill expert survey. The wording of this question is: "Political scientists often classify parties in terms of their ideological stance on economic issues. Parties to the right emphasize a reduced economic role for government. They want privatization, lower taxes, less regulation, reduced government spending, and a leaner welfare state. Parties to the left want government to play an active role in the economy. Using these criteria, indicate where parties are located in terms of their economic ideology." 0 indicates that a party is at the extreme left of the ideological spectrum, 10 that it is at the extreme right, and 5 that it is at the centre.
} 
In total we examine six hypotheses relating to salience of and party position on the Constitution. These propositions are derived from the earlier discussion about salience theory and cleavage theory. Two hypotheses refer to salience and four to party position.

Concerning salience of the Constitution we start from the proposition that the more that other parties in the political system emphasise the Constitution as an issue, the higher the salience of the Constitution to a party (Hypothesis 1). This hypothesis tests the relationship between systemic salience and the salience that each party assigns to the Constitution. One might speculate that national salience of the Constitution is also related to polarisation in public attitudes toward the Constitution. To determine this, we test whether there is a relationship between the salience that all parties in a country assign to the Constitution and the degree to which public opinion is polarised on the issue. Specifically, we examine whether it is true that the more a country's public is polarised over the Constitution, the more that country's parties will assign salience to this topic (Hypothesis 2).

Concerning party position on the Constitution, the following hypotheses are formulated: first, the more a party is located at the extreme end of the ideological spectrum, the less likely that it will be in favour of the Constitution (Hypothesis 3). Second, the greater a party's internal divisions over European integration, the less likely that it will be in favour of the Constitution (Hypothesis 4). Internal division over Europe might deter a party from taking a bold stance on the Constitution. Third, the more that a party has a positive attitude toward the EU, the more likely that it will also take a positive position on the Constitution (Hypothesis 5). Fourth, parties that participated in the Constitutional Convention are more likely to take a positive position on the Constitution (Hypothesis 6). Participation in the Constitutional Convention can be expected to have an impact on the position that a party is likely to take on the Constitution (Pennings and Arnold 2008; Collignon 2003).? Given the difference between the experience of the parties that participated in the Convention ('insiders') and the parties that did not participate ('outsiders') we expect to find variance in the degree to which each party is for or against the Constitution (Crum 2005: 5). ${ }^{8}$

\section{Empirical Findings}

In this section the empirical analysis assesses the extent to which the salience that parties assign to the Constitution can be explained by the political environment in which they operate and also to what extent it is related to national public opinion on the Constitution. This section also analyses the extent to which the positions that parties take on the Constitution is related to their left/right stance, internal party divisions over the issue, their overall position on European integration, and whether or not they participated in the Constitutional Convention. The analysis proceeds in two steps. First, we analyse the salience of the Constitution. In addition, we examine whether the variation in issue salience is related to public opinion. Second, we analyse party positions on the Constitution. We use a set of descriptive statistics (scatterplot, arithmetic mean and standard deviation) to examine which of our six hypotheses can be confirmed.

\footnotetext{
7 'Insiders' and 'outsiders' are identified by means of a list of all parties participating in the Constitutional Convention. Parties on the list are coded as 'insiders' and parties not on the list as 'outsiders'.

8 On the Constitution see Crum 2005; Dinan 2004; Kiljunen 2004; Kokott and Rüth 2003; Schmitter 2000; Shaw 2003; Norman 2003; and Nugent 2006. This paper focuses on parties which belong to member states who had joined the EU prior to 1 May 2004. The manifestos of the new member states were not used in this paper, since we are interested in the impact that participation in the Constitutional Convention had on the position a party took on the Constitution. The individuals of parties of the new member states were only observers in the Convention and therefore had a rather different status to the individuals of parties of the old member states.
} 


\section{Explaining the Salience of the Constitution}

One of the questions we ask in this paper is: When national parties assign salience to the Constitution, is this related to the salience that the other parties of the same political system have assigned to the Constitution? In other words, is the salience for one party affected by the systemic salience (Hypothesis 1)? We define the degree of disparity of a party as the absolute value of the difference between the salience assigned by that party and the systemic salience with respect to the same party. In graph (1) a simple comparison of the national salience (i.e. the average of all the party saliences) and the mean disparity (i.e. the average of all the party disparities) demonstrates that, at the national level, there is a strong negative correlation.

Graph 1: National salience and mean disparity, by country

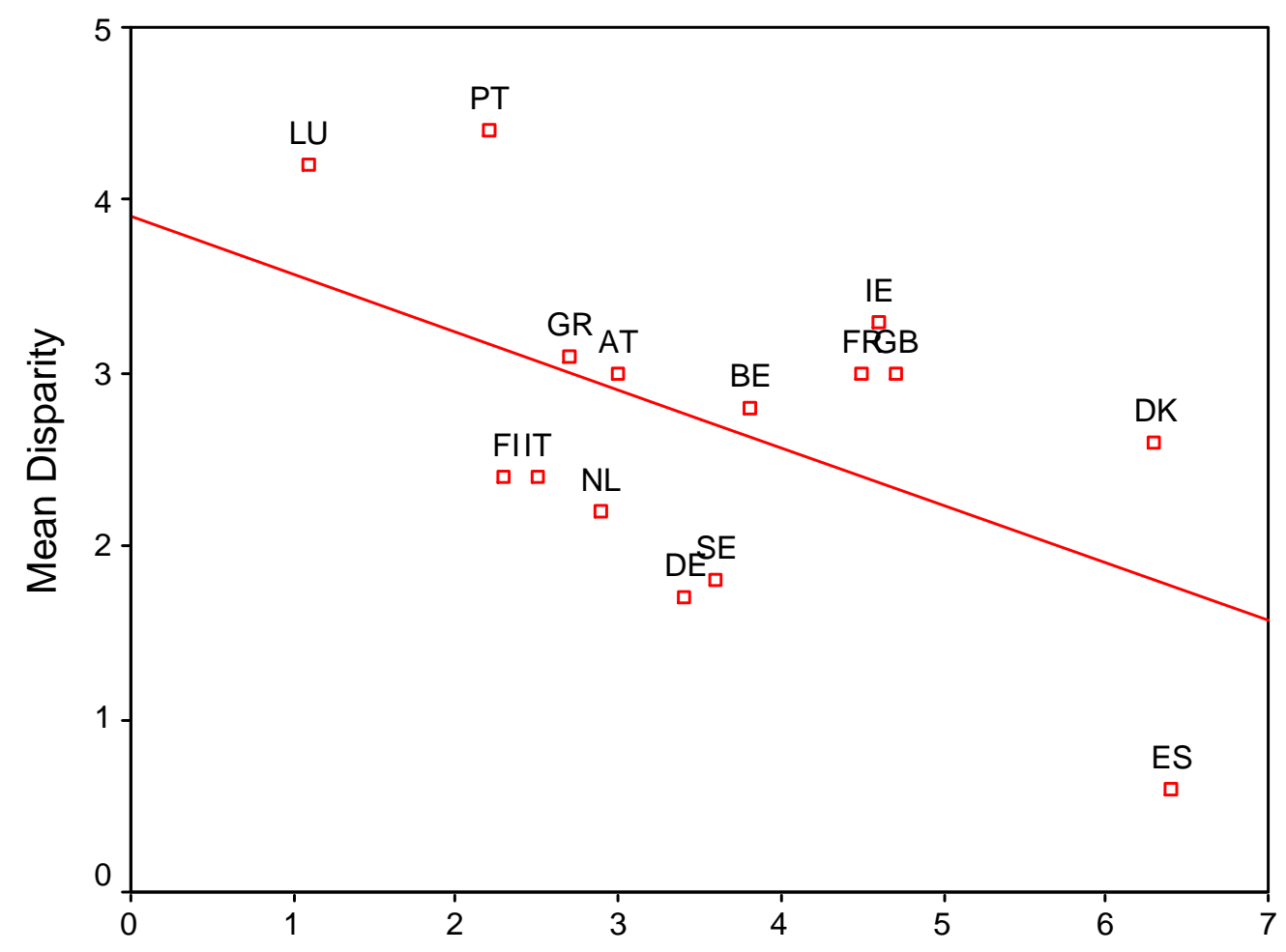

National Salience

Source: Own calculations based on content analysis of party manifestos

This graph largely confirms Hypothesis 1 which states that if some parties in a country assign salience to the Constitution, then the other parties are also likely to be drawn into debating the issue and assigning salience. The trendline in the scatterplot indicates a negative relationship in the sense that when the national salience is low, the disparity is mostly high, e.g., Luxembourg and Portugal, whereas when the national salience is high, the mean disparity tends to be very low, e.g., Spain. In the cases of Luxembourg and Portugal, we find that there are parties that deviate considerably from the national salience either by emphasising the Constitution issue considerably more than the other parties or by mentioning the issue much less. Conversely, in the case of Spain, where national salience is high and mean disparity is low, we find that parties assign about the same, relatively high, salience to the topic. The remaining countries cluster in the middle of the scatterplot. On a descriptive level, this indicates that Hypothesis 1 is confirmed. The salience of the Constitution for a party is indeed related 
to the salience that the other parties have assigned to the issue. The more that other parties in the political system emphasise the Constitution as an issue, the higher the salience of the Constitution for a party.

The results of a simple regression also indicate that national salience and mean disparity are related. The regression has a fair fit (R-square adjusted $=27 \%)$, but, more important, the overall relationship is statistically significant $(\mathrm{F} 1,13=4.89, \mathrm{t} 13=-2.2, \mathrm{p}<$ $0.05)$. Mean disparity scores are negatively related to national salience, decreasing by 0.52 for every unit increase in national salience. This analysis confirms the hypothesis that the salience a party assigns to the Constitution is indeed influenced by the salience that other parties of the same political system have assigned to the issue. The negative coefficients indicate that as national salience increases, the mean disparity among the parties in a given system decreases. In other words, when some parties in the political system emphasise the Constitution as an issue, other parties in the same political system are very likely to put about the same amount of emphasis on it. This finding implies that the Constitution is an issue that no party can easily ignore, unless most parties neglect it.

One might speculate that national salience of the Constitution is related to polarisation in public attitudes toward the Constitution, with national salience increasing the more that a country's population is polarised over the issue. In other words, perhaps there could be a relationship between the salience all parties in a country attribute to the Constitution and the degree to which public opinion is polarized over the issue. One would expect to find that the more a country's public is polarized over the issue, the more national salience should increase (Hypothesis 2). ${ }^{9}$ In our study, polarisation is measured using the Eurobarometer question about the Constitution. ${ }^{10}$ In graph (2) a comparison of the heterogeneity of public opinion on the Constitution and national salience (i.e. the average of all of the party saliences on the Constitution) demonstrates what appears to be a positive correlation.

Countries with low heterogeneity of public opinion, e.g., Luxembourg and Italy, tend to have low national salience as well. Conversely, countries with high heterogeneity of public opinion, e.g., Denmark, show high national salience. The results of a simple regression indicate that heterogeneity of public opinion and national salience are related. The regression has a fair fit (R-square adjusted $=25 \%$ ) and the overall relationship is statistically significant $(\mathrm{F} 1,13=7.21, \mathrm{t} 13=2.08, \mathrm{p}<0.05)$. This analysis confirms Hypothesis 2, which states that the salience parties assign to the Constitution is related to polarisation in public attitudes toward the Constitution.

\footnotetext{
${ }^{9}$ To operationalise polarisation over an issue we use the 'variance' of public opinion across answer categories in the Eurobarometer survey question. We use an indicator of heterogeneity based on Lieberson (1969) and elaborated in Sullivan (1973) and Anderson (2005), reflecting the level of consensus in domestic public opinion. The indicator, to be called "Heterogeneity of Public Opinion" in our analysis, is calculated as
}

$$
A_{W}=1-\left(\sum_{k-1}^{p} Y_{k}^{2} / V\right)
$$

where $A_{w}$ denotes diversity within a population, $Y_{k}$ is the proportion of the population falling in a given category within each of the variables, $V$ is the number of variables, and $p$ represents the total number of categories within all of the variables. Larger values of this indicator represent more heterogeneity in public opinion.

10 This is question 29.6 in Eurobarometer survey 61.0. 
Graph 2: Heterogeneity of Public Opinion and national salience, by country

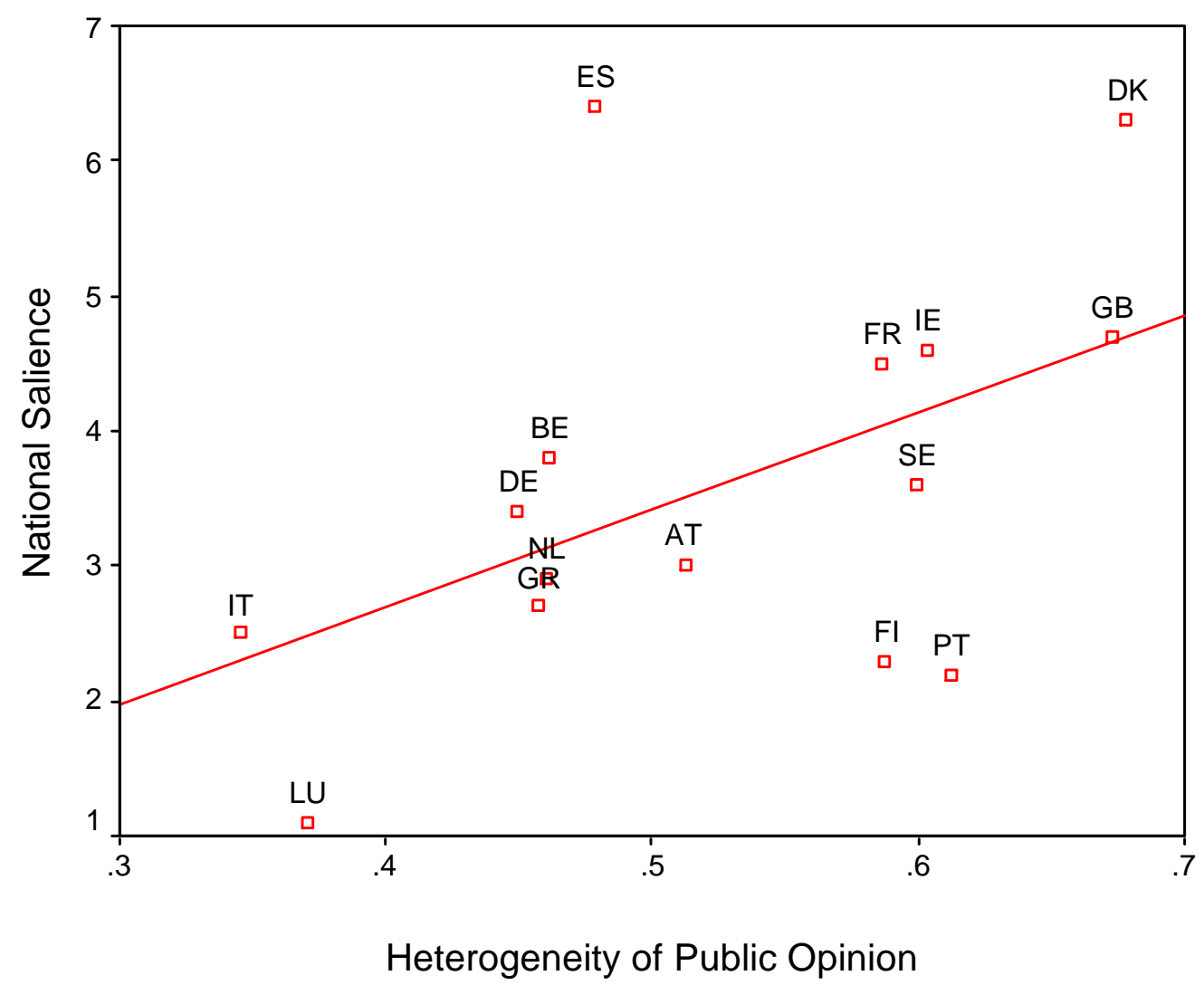

Sources: Eurobarometer 61.0 and own calculations based on content analysis of party manifestos

\section{Explaining a Party's Position on the Constitution}

Is there a relationship between the ideological stance of a party and its position on the Constitution (Hypothesis 3)? Using descriptive measures, table (2) shows that there is such a relationship. ${ }^{11}$ We find that the left/right stance is related to the position a party takes on the Constitution. ${ }^{12}$ Radical parties, particularly on the right but also on the left, have a negative attitude toward the Constitution. Parties of the centre are most likely to have a positive position on the Constitution. Table (2) shows that this relationship is statistically significant. Disaggregating by party family, the same pattern emerges: radical party families Europe of Democracies and Diversities (EDD) and Greens take a distinctly negative position on the Constitution; party families European United Left/Nordic Green Left (EUL/NGL) and Union for Europe of the Nations (UEN) have relatively low mean scores; while centre party families the Party of European Socialists (PES), the European Liberal Democratic and Reform Party (ELDR) and the European People's Party and European Democrats (EPP-ED) take by far the most positive position on the Constitution.

\footnotetext{
${ }^{11}$ Although we have collected 100 party manifestos we do not use all of them in this table. The difference stems from the fact that the expert data set from Chapel Hill and Benoit and Laver does not include all of these 100 parties.

${ }^{12}$ The definition of left/right corresponds to the data from the Chapel Hill expert survey. Values of 1 through 3 correspond to left, values of 4 through 7 correspond to centre, and values of 8 through 10 correspond to right.
} 
Table 2: Determinants of Party Position on the Constitution

\begin{tabular}{|c|c|c|c|c|}
\hline & \multicolumn{2}{|c|}{$\begin{array}{l}\text { Position on } \\
\text { Constitution }\end{array}$} & \multirow[t]{2}{*}{$\mathrm{n}$} \\
\hline & & Mean & SD & \\
\hline \multirow{5}{*}{ Left/Right } & Left & 2.11 & 4.51 & 31 \\
\hline & Centre & 5.10 & 5.81 & 28 \\
\hline & Right & 0.79 & 3.73 & 28 \\
\hline & $E t a^{2}$ & $0.13^{* * *}$ & & \\
\hline & $F$ & 6.05 & & \\
\hline \multirow{9}{*}{ Party Family } & EUL/NGL & 2.64 & 2.87 & 18 \\
\hline & PES & 3.52 & 6.20 & 13 \\
\hline & Greens/EFA & -0.90 & 4.18 & 13 \\
\hline & ELDR & 3.45 & 3.96 & 14 \\
\hline & EPP-ED & 6.68 & 5.83 & 11 \\
\hline & UEN & 2.28 & 5.26 & 14 \\
\hline & EDD & -1.27 & 3.36 & 4 \\
\hline & $E_{t a}^{2}$ & $0.28 * * *$ & & \\
\hline & $F$ & 5.26 & & \\
\hline \multirow[t]{5}{*}{ Dissent } & United & 2.64 & 5.04 & 30 \\
\hline & Minor dissent & 1.85 & 4.70 & 29 \\
\hline & Divided & 4.90 & 7 & 11 \\
\hline & $E t a^{2}$ & \multicolumn{2}{|c|}{0.04} & \\
\hline & $F$ & \multicolumn{2}{|c|}{1.35} & \\
\hline \multirow[t]{5}{*}{ Position } & Opposed & -2.25 & 4.07 & 15 \\
\hline & Neutral & $\mid-0.43$ & 4.01 & 8 \\
\hline & In Favour & 4.77 & 4.49 & 47 \\
\hline & $E t a^{2}$ & \multicolumn{2}{|c|}{$0.34^{* * *}$} & \\
\hline & $F$ & \multicolumn{2}{|c|}{17.05} & \\
\hline \multirow{4}{*}{ Insider/Outsider } & Outsider & $\mid-0.14$ & 4.41 & 24 \\
\hline & Insider & 4.13 & 5.13 & 46 \\
\hline & $E t a^{2}$ & \multicolumn{2}{|c|}{$0.15^{* * *}$} & \\
\hline & $F$ & \multicolumn{2}{|c|}{12.03} & \\
\hline
\end{tabular}

Significance: ${ }^{* *} p<0.001,{ }^{* *} p<0.05,{ }^{*} p<0.10$

Concerning the relationship between how divided a party is over European integration and its position on the Constitution (Hypothesis 4) we find that parties that are united are quite similar in their position on the Constitution compared to parties that have only minor dissent. The average scores are 2.64 and 1.85 respectively. Furthermore, counterintuitive to Hypothesis 4, parties that are divided have a positive attitude towards the Constitution, albeit with a large standard deviation. The respective scores are 4.9 and 7. This indicates that Hypothesis 4, which states that the greater a party's internal division over European integration the less likely that it will be in favour of the Constitution, cannot be confirmed.

Concerning the question whether a party's overall position on European integration is related to its position on the Constitution (Hypothesis 5), table (2) indicates that such a relationship does exist. Parties opposed to European integration have distinctly negative mean scores $(-2.25)$ compared to parties that are neutral $(-0.43)$ or in favour (4.77). These descriptive measures confirm Hypothesis 5. We hypothesised that the more a party takes a positive position on European integration the more it will take a 
positive position on the Constitution. A party's general inclination towards the EU does appear to be related to its general attitude towards the European Constitution.

Finally, we turn to the question whether a party's participation or non-participation in the Constitutional Convention is related to its position on the Constitution (Hypothesis 6). Table (2) clearly indicates that participants in the Constitutional Convention insiders - were by far more positive about the Constitution than non-participants - the outsiders. ${ }^{13}$ This confirms our hypothesis that participating in the Constitutional Convention coincides with a more positive position on the Constitution.

Concerning which factors indicate what position a party is likely to take on the Constitution, the descriptive analysis and measures of association so far indicate that among the variables tested only the left/right ideological stance, the overall position on European integration, and the insider/outsider status of a party have an impact. We now use multiple regression analysis to determine the relative impact of each factor when the other predictor variables are held constant. The results are shown in table (3). We find that the strongest predictor of party position is its overall position on European integration (with a coefficient of 0.46 ) followed by a party's insider/outsider status (with a coefficient of 0.22 ). Both of these variables are significant at the $p<0.001$ level. Also significant is a party's left/right stance.

Table 3: Multiple Regression Analysis for Position on Constitution

\begin{tabular}{|l|c|}
\multicolumn{2}{|c|}{$\begin{array}{c}\text { Standardised coefficients } \\
\text { (t-values) }\end{array}$} \\
\hline & $\begin{array}{c}\text { Position on } \\
\text { Constitution }\end{array}$ \\
\hline Left/Right & $-0.20^{*}$ \\
& $(-1.95)$ \\
\hline Dissent & 0.05 \\
& $(0.43)$ \\
\hline Position & $0.46^{* * *}$ \\
& $(3.91)$ \\
\hline Insider/Outsider & $0.22^{* * *}$ \\
& $(1.78)$ \\
\hline $\mathrm{R}^{2}$ & 0.34 \\
$\mathrm{~F}$ & 8.50 \\
$\mathrm{n}$ & 70 \\
& \\
\hline
\end{tabular}

Significance: ${ }^{* *} p<0.001,{ }^{* *} p<0.05,{ }^{*} p<0.10$

Is there a relationship between the salience a party assigns to the Constitution and the position this party takes on the Constitution, for example, are parties assigning high salience to the Constitution also more likely to be in favour of it? Graph (3) shows a number of counter examples to this assertion, that is, the parties along the downward sloping line. These parties assign high salience to the Constitution and take a negative position on it. Beyond this insight, the graph also contains some additional information. Round markers signify that a party participated in the Constitutional Convention. Triangle markers indicate that a party did not participate in the Convention. The size of both markers is proportional to a party's share of the vote in the 2004 EP elections.

\footnotetext{
13 Participation could have been either as a representative of government, national Parliament or the European Parliament, and either as full member or alternate.
} 
Graph 3: Salience Constitution and Position on the Constitution, by party

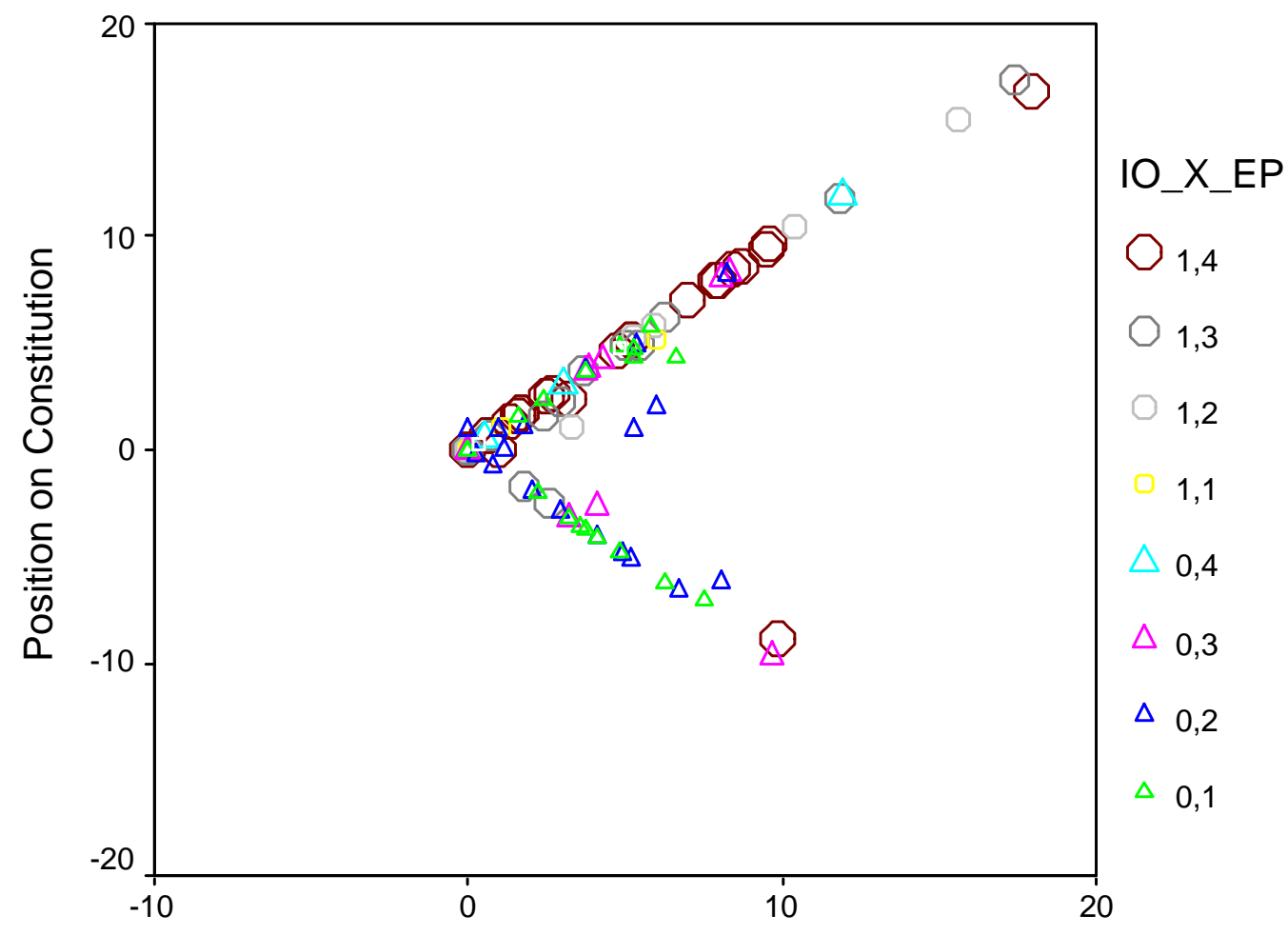

Salience Constitution

Source: Own calculations based on content analysis of party manifestos

Graph 3 shows that almost all of the parties situated on the downward slope are parties that did not participate in the Constitutional Convention. We find only three exceptions: the Swedish Vänsterpartiet, the Italian Alleanza Nazionale and the British Conservative Party. These three parties participated in the Convention and yet were markedly negative about the Constitution in their manifestos. The upward slope contains some parties that did not participate in the Convention, but is otherwise dominated by participants. Given the strong correlation between a party's insider/outsider status and its position on the Constitution, one can expect to find that the 2004 EP elections was only one front of a larger battlefield. The results of the referenda on the Constitution in France and the Netherlands (May/June 2005) were perhaps the first indications of the ability of the euroskeptic quarters to mobilise against the EU. Whereas insiders had dominated the discussions about the Constitution at the Constitutional Convention, and on the whole received more votes in the 2004 EP elections, outsiders might have dominated the discussions about the Constitution and taken the lead in these two referenda.

\section{Conclusion}

One recent concern in the political science literature is how European integration affects party competition. This paper contributes to the debate by considering the positions on the EU Constitution taken by parties during the 2004 EP elections. Through content analysis of party manifestos of national parties, we examined salience (the number of sentences devoted to the Constitution) and direction (whether for or against the Constitution). 
Assessing what salience parties assigned to and their position on the Constitution during the 2004 EP elections contributes to discussions about the nature of EP elections. However, the extent to which national parties actually do discuss the Constitution can indicate more how strategically useful they think it is to address European issues during an election campaign. Examination of systemic salience shows that, rather than viewing EP elections as being either second-order elections, with European issues playing second fiddle to national issues, or European elections representing real transnational policy choices, it is more insightful to examine how far national parties vary in their strategic use of a European issue during election campaigns. This finding adds an important element to the salience theory that we discussed earlier, namely, that the salience of European issues is not simply related to issue ownership by particular parties, but results from the interaction of parties within a national party system.

Additionally, we have found a statistically significant relationship between heterogeneity of public opinion and the salience parties assign to the Constitution. Heterogeneity of public opinion is a fair predictor of the salience parties in a given country assign to the Constitution.

Concerning additional predictor variables for party position on the Constitution, we find that the strongest predictor is a party's insider/outsider status at the Constitutional Convention, followed by a party's overall position on European integration, and, finally, its left/right ideological stance. This pattern shows that in addition to the central proposition of cleavage theory that ideology matters (i.e. left/right), there are also important additional factors that matter and influence a party's position on the Constitution.

There is increasing evidence that national parties, while using EP elections to position themselves in the national arena, cannot insulate themselves fully from the issues discussed at the EU level (Ray 1999; Marks et al. 2002; Arnold and Pennings 2005). Instead, during election campaigns, parties can strategically exploit European issues as a means to differentiate themselves from perceived competitors. In line with the experience of the constitutional referenda in France and the Netherlands, this article presents empirical evidence that Constitutional Convention insiders defined the political space in favour of the Constitution during the 2004 EP elections. Convention 'outsiders' used the 2004 EP elections as a platform to oppose the Constitution and as a warm-up for their campaigns against the Constitution in ensuing referenda. 


\section{References}

Anderson, C. (2005). 'Consent and Consensus: The Contours of Public Opinion toward the Euro', in A. Messina and R. Fishman (eds.), The Year of The Euro: The Cultural, Social and Political Import of Europe's Single Currency. Notre Dame: University of Notre Dame Press.

Arnold, C. and Pennings, P. (2005). 'Party Groups and the Main Issue Dimensions of the European Parliament Election in 2004', Proceedings of the European Union Studies Association Conference, Austin, TX, 31 March - 2 April 2005.

Attina, F. (1990). 'The Voting Behavior of the European Parliament Members and the Problem of the Europarties', European Journal of Political Research, 18, pp. 557579.

Bara, J. (2001). 'Using Manifesto Estimates to Validate Computerized Analysis,' in I. Budge, H.-D. Klingemann, A. Volkens, J. Bara and E. Tanenbaum (eds.), Mapping Policy Preferences: Estimates for Parties, Electors and Governments, 1945-1998. Oxford: Oxford University Press, pp. 143-156.

Benoit, K., Laver, M., Arnold, C., Pennings, P. and Hosli, M. O. (2005). 'Measuring National Delegate Positions at the Convention on the Future of Europe Using Computerized Wordscoring', European Union Politics, 6 (3), pp. 291-313.

Benoit, K. and Laver, M. (2006). Party Policy in Modern Democracies. London: Routledge.

Budge, I. and Farlie, D. J. (1983). Explaining and Predicting Elections: Issue Effects and Party Strategies in Twenty-Three Democracies. London: George Allen \& Unwin.

Budge, I., Klingemann, H.-D., Volkens, A., Bara, J. and Tanenbaum, E. (eds.) (2001). Mapping Policy Preferences: Estimates for Parties, Electors, and Governments 19451998. Oxford: Oxford University Press.

Collignon, S. (2003). The European Republic. Reflections on the Economy of a Future Constitution. London: Federal Trust for Education and Research/Bertelsmann Foundation.

Crum, B. (2005). 'Confusing Cues: Competition of Party Strategies in Referendums on the EU Constitution', Proceedings of the 2005 epsNet Conference, Paris, 17-18 June 2005.

Crum, B. (2007). 'Party Stances in the Referendums on the EU Constitution: Causes and Consequences of Competition and Collusion', European Union Politics, 8, pp. 6182.

Dinan, D. (2004). 'Governance and Institutions: The Convention and the Intergovernmental Conference', Journal of Common Market Studies 42 (Annual Review) pp. 27-42.

Eijk, C. van der, and Franklin, M. (1996). Choosing Europe? The European Electorate and National Politics in the Face of the Union. Ann Arbor: University of Michigan Press.

Franklin, M. N., Marsh, M. and McLaren, L. (1994). 'Uncorking the Bottle: Popular Opposition to European Unification in the Wake of Maastricht', Journal of Common Market Studies, 32 (4), pp. 455-72.

Gabel, M. and Hix, S. (2002). 'Defining the EU Political Space', Comparative Political Studies, 35 (8), pp. 934-964.

Hix, S. (1999). 'Dimensions and Alignments in European Union Politics: Cognitive Constraints and Partisan Responses', European Journal of Political Research, 35, pp. 69-106.

Hix, S. (2001). 'Legislative Behaviour and Party Competition in the European Parliament: An Application of Nominate to the EU', Journal of Common Market Studies, 39 (4), pp. 663-688.

Hix, S., Kreppel, A. and Noury, A. (2003). 'The Party System in the European Parliament: Collusive or Competitive?', Journal of Common Market Studies, 41 (2), pp. 309331.

Hooghe L. et al. (2009) Chapel Hill Expert Survey. Available at: http://www.unc.edu/ hooghe/data pp.php, last accessed 9 April 2009. 
Hooghe, L. and Marks, G. (2009). 'A Postfunctional Theory of European Integration: From Permissive Consensus to Constraining Dissensus', British Journal of Political Science, 39 (1), pp. 1-23.

Hooghe, L., Marks, G. and Wilson, C. J. (2004). 'Does Left/right Structure Party Positions on European Integration?', in G. Marks and M. Steenbergen (eds.), European Integration and Political Conflict. Cambridge: Cambridge University Press, pp. 120-140.

Irwin, G. (1995). 'Second-Order or Third-Rate? Issues in the Campaign for the Elections for the European Parliament 1994', Electoral Studies, 14, pp. 183-199.

Kiljunen, K. (2004). The EU Constitution: A Finn at the Convention. Publications of the Parliamentary Office 1/2004.

Kleinnijenhuis, J. and Pennings, P. (2001). 'Measurement of Party Positions on the Basis of Party Programmes, Media Coverage and Voter Perceptions', in M. Laver (ed.), Estimating the Policy Positions of Political Actors. London: Routledge, pp. 101-182.

Klingemann, H.-D., Hofferbert, R. I. and Budge, I. (eds.) (1994). Parties, Politics, and Democracy. Boulder, Colorado: Westview Press.

Kokott, J. and Rüth, A. (2003). 'The European Convention and its Draft Treaty Establishing a Constitution for Europe: Appropriate answers for the Laeken Questions?', Common Market Law Review, 40 (6), pp. 1315- 1345.

König, T. and Hug, S. (eds.) (2006). Policy-Making Processes and the European Constitution: A Comparative Study of Member States and Accession Countries. London: Routledge.

Kreppel, A. and Tsebelis, G. (1999). 'Coalition Formation in the European Parliament: Past, Present and Future', European Union Politics, 1, pp. 340-362.

Laver, M., Benoit, K. and Garry, J. (2003). 'Extracting Party Positions from Political Texts Using Words as Data', American Political Science Review, 97 (2), pp. 311-331.

Laver, M. (ed.) (2001). Estimating the Policy Positions of Political Actors. London: Routledge.

Laver, M. and Garry, J. (2000). 'Estimating Policy Positions from Political Texts', American Journal of Political Science, 44 (3), pp. 619-634.

Lieberson, S. (1969). 'Measuring Population Diversity', American Sociological Review, 34 (6), pp. 850-862.

Mair, P. (2001). 'The Limited Impact of Europe on National Party Systems', in K. H. Goetz and S. Hix (eds.), Europeanized Politics? European Integration and National Political Systems. London: Frank Cass, pp. 27-51.

Mair, P. (2007). 'Political Parties and Party Systems', in P. Graziano and M. Vink (eds.), Europeanization: New Research Agendas. Basingstoke: Palgrave Macmillan.

Marks, G. and Steenbergen, M. (eds.) (2004). European Integration and Political Conflict. Cambridge: Cambridge University Press.

Marks, G., Wilson, C. J. and Ray, L. (2002). 'National Political Parties and European Integration', American Journal of Political Science, 46 (3), pp. 585-594.

Marks, G. and Wilson, C. J. (2000). 'The Past in the Present: A Cleavage Theory of Party Response to European Integration', British Journal of Political Science, 30, pp. 433-459.

Norman, P. (2003). The Accidental Constitution: The Story of the European Convention. Brussels: EuroComment.

Nugent, N. (2006). The Government and Politics of the European Union. 6th Edition. 'The Constitutional Treaty', Durham: Duke University Press, pp. 116-128.

Pennings, P. (2002). 'The Dimensionality of the EU Policy Space', European Union Politics, 3 (1), pp. 59-80.

Pennings, P. (2006). 'An Empirical Analysis of the Europeanisation of National Party Manifestos, 1960-2003', European Union Politics, 7 (2), pp. 257-270.

Pennings, P. and Arnold, C. (2008). 'Is Constitutional Politics Like "Normal Politics"? The case of the EU Constitution', Political Studies, 56 (4), pp. 789-806.

Pennings, P., Arnold, C. and Hosli, M. O. (2004). 'The European Constitution and Positions on Governance', Proceedings of the ECPR Conference, Uppsala, April 1318, 2004. 
Pennings, P. and Keman, H. (2002). 'Towards a New Methodology of Estimating Party Policy Positions', Quality \& Quantity, 36, pp. 55-79.

Poguntke, T., Aylott, N., Carter, E., Ladrech, R. and Luther, K. R. (2007). The Europeanization of National Political Parties. Power and Organizational Adaptation. London and New York: Routledge.

Ray, L. (1999). 'Measuring Party Orientations towards European Integration: Results from Expert Survey', European Journal of Political Research, 36, pp. 283-306.

Reif, K. and Schmitt, H. (1980). 'Nine Second Order National Elections: A Conceptual Framework for the Analysis of European Election Results', European Journal of Political Research, 8, pp. 3-44.

Riker, W. (1982). Liberalism Against Populism. A Confrontation between the Theory of Democracy and the Theory of Social Choice. San Francisco: W H Freeman and Co.

Schmitt, H. and Thomassen, J. (eds.) (1999). Political Representation and Legitimacy in the European Union. Oxford: Oxford University Press.

Schmitter, P. C. (2000). 'An Excursus on Constitutionalization'. Constitutionalism WebPapers, No. 3/2000.

Shaw, J. (2003). 'Process, Responsibility and Inclusion in EU Constitutionalism.' European Law Journal, 9 (1), pp. 45-68.

Steenbergen, M. and Marks, G. (2007). 'Evaluating Expert Surveys,' European Journal of Political Research, 46(3), pp. 347-366.

Steenbergen, M. and Scott, D. J. (2004). 'Contesting Europe? The salience of European integration as a party issue', in G. Marks and M. Steenbergen (eds.), European Integration and Political Conflict. Cambridge: Cambridge University Press, pp. 165-192.

Sullivan, J. L. (1973). 'Political Correlates of Social, Economic, and Religious Diversity in the American States', Journal of Politics, 35 (1): pp. 70-84.

Thomassen, J., Noury, A. G. and Voeten, E. (2004). 'Political Competition in the European Parliament: Evidence from roll call and survey analysis', in G. Marks and M. Steenbergen (eds.), European Integration and Political Conflict. Cambridge: Cambridge University Press, pp. 141-164.

Tsebelis, G. (2005). 'Assessing the Contributions of the Dosei Project', European Union Politics, 6 (3), pp. 377-390. 